\title{
Resonancias de los Tratados de Madrid (1750) y San Ildefonso (1777) en las lecturas sobre la formación del territorio de los Estados de Argentina y Brasil ${ }^{\star}$
}

Perla Zusman

Conicet-Universidad de Buenos Aires (Argentina)

perlazusman@yahoo.es

Sergio Nunes

Universidad Federal Fluminense (Niterói, Brasil)

snunes.rio@uol.com.br

Fecha recepción 13.07.2018 / Fecha aceptación 15.01.2019

\section{Resumen}

Las firmas de los Tratados de Madrid (1750) y San Ildefonso (1777) entre las Coronas española y portuguesa fueron reflejo del interés por establecer una forma de ejercicio del poder que evitara la instalación de otras potencias en las áreas coloniales bajo dominio de ambas metrópolis. Estos tratados y la cartografía producida por las partidas demarcadoras fueron recuperadas por los Estados de Argentina y Brasil en el momento de su constitución para definir sus límites internacionales y para dirimir conflictos

\section{Abstract}

The signing of the Treaties of Madrid (1750) and San Ildefonso (1777) between the Spanish and Portuguese Crowns reflects an interest in establishing power without installing potentates in colonial areas under the control of the two Empires. The treaties and the cartography produced by the demarcating parties were adopted by the States of Argentina and Brazil to define their international boundaries and to resolve any conflict arising during the demarca-

\footnotetext{
* Trabajo realizado en el marco del proyecto CSO2015-65301-P (MINECO/ FEDER).
} 
que surgieron en los procesos de demarcación hacia finales del siglo XIX y principios del XX. En este artículo nos interesa identificar las repercusiones de dichos tratados en la literatura producida en las Ciencias Sociales en Argentina y Brasil en torno a la geografía histórica del Río de la Plata. En particular, deseamos comprender qué visiones de la frontera y el territorio ofrecen los textos relevados. Dentro de este marco, entendemos que la identificación de estas perspectivas puede contribuir, por un lado, a entender las implicancias socio-territoriales de la firma de los tratados en los procesos de formación de los Estados Nacionales y, por el otro, a reconocer las potencialidades y limitaciones de dichos estudios para analizar las dinámicas que tuvieron lugar en el Río de la Plata hacia mediados del siglo XVIII.

\section{Palabras claves}

Tratados de Madrid y San Ildefonso, Estado-Nación, Argentina, Brasil, Frontera, Territorio. tion processes in the late 19th/early 20 th century. This article seeks to identify the echoes of these treaties in the literature produced in the social sciences in Argentina and Brazil around the historical geography of the River Plate, with the aim of understanding the conceptions of boundary and territory that underlie these perspectives. Within this framework, we consider that the identification of these visions can help understand, on the one hand, the socio-territorial implications of the signing of the treaties in the formation processes of the National States, and on the other hand, the potentialities and limitations of these studies in analysing the dynamics that took place in the River Plate towards the middle of the 18th century.

\section{Keywords}

Treaties of Madrid and San Ildefonso, nation-state, Argentina, Brazil, frontier, territory. 


\section{Contexto y contenidos de los tratados de Madrid y San Ildefonso}

En el año 1986 el cineasta franco-británico Roland Joffé filma la película La Misión. Con la actuación de Jeremy Irons y Robert de Niro, y bajo la influencia de la imponente escenografía de las Cataratas del Iguazú, el cineasta procura recrear las implicaciones del tratado de Madrid firmado en el año 1750 entre España y Portugal en términos de desalojo de las Misiones Jesuíticas. La pieza cinematográfica pone el foco en el enfrentamiento espiritual y bélico que tiene lugar entre las Coronas y la alianza entre Jesuitas y guaraníes.

De esta manera la película refleja uno de los propósitos de la firma del acuerdo de Madrid y, más tarde, el de San Ildefonso (1777) en el área América Meridional: el interés por legitimar el proceso de ocupación que ponía en cuestión la distribución territorial realizada por el Tratado de Tordesillas, la búsqueda por establecer una forma de organización territorial que se impusiera por sobre otras pre-existentes como aquellas que representaban las misiones jesuíticas, o aquellas propias de las poblaciones indígenas. A su vez, se deseaba evitar la instalación de otras potencias coloniales en el área y la expansión del contrabando ${ }^{1}$.

Estos propósitos se acompañaron de otros que perseguían la definición de territorios que quedaban bajo el dominio de cada una de las Coronas. Los Tratados en cuestión daban cuerpo a los criterios consensuados en las negociaciones. Por un lado, el de uti possidettis (la defensa del derecho de posesión de aquellos ámbitos que habían sido efectivamente ocupados) y, por el otro, el de frontera natural, es decir la definición del límite intercolonial a partir

1. L. A. Ribot García, A. Carrasco Martínez y L.A. Da Fonseca, El Tratado de Tordesillas y su época. Congreso Internacional de Historia, Sociedad V Centenario del Tratado de Tordesillas. 1687-1700. Valladolid, 1995; P. Zusman. Tierras para el Rey. Tres fronteras y la construcción colonial del territorio del Río de la Plata (1750-1790). Tesis Doctoral Universitat Autònoma de Barcelona, Bellaterra, 2000. 
de elección de un elemento de la naturaleza (el origen o recorrido del curso de un río o los montes considerados como «más notables»). Se suponía que el uso del criterio de frontera natural aseguraría la definición de las divisas de modo claro y preciso, y que estas no serían objeto de alteraciones a través del tiempo ${ }^{2}$.

En el área del Río de la Plata, el tratado de Madrid contempló la cesión portuguesa de la Colonia de Sacramento y la entrega española del territorio situado al oriente de río Uruguay. Esto último supondría el traslado de las misiones guaraníes que se hallaban en la margen oriental del río Uruguay. La firma del tratado encontró oposición en las metrópolis y en las colonias. Las guerras guaraníticas y algunos conflictos surgidos en las propias acciones demarcatorias en el terreno llevaron a derogar el tratado en el año 1761 (Tratado del Pardo).

En 1777 se firmó del Tratado de San Ildefonso por el cual la Corona española aseguraba su dominio sobre el Río de la Plata, Colonia de Sacramento y el margen oriental del río Uruguay (incluyendo el área que había correspondido a las misiones guaraníes), mientras que la Isla de Santa Catalina era devuelta a los portugueses. Las comisiones demarcatorias iniciaron sus actividades en 1781 y abandonaron América Meridional en 1801, sin finalizar sus actividades. La firma del acuerdo de Badajoz en dicho año, ya en el contexto de las guerras napoleónicas, creó un nuevo impasse que abrió el espacio para el enfrentamiento entre ambos Imperios y para el inicio de acciones de ocupación de los territorios pretendidos de dominación, no cedidos por los tratados anteriores.

Las resoluciones de los Tratados de Madrid y San Ildefonso serán ampliamente incorporadas en las negociaciones diplomáticas de los estados nacionales latinoamericanos que se comienzan a conformar en el siglo XIX. Los criterios de uti possidetis (entendido ahora como las herencias de unidades jurídico-administrativas de los tiempos coloniales) y de fronteras naturales serán tomados en cuenta en el proceso de determinación de los territorios de los estados nacionales. A su vez, los reconocimientos en el terreno realizados por parte de las partidas demarcadores y la cartografía producidas por las mismas serán utilizados en la resolución de los conflictos que emergieron en el proceso de definición de los límites entre los estados.

En este artículo nos interesa identificar las repercusiones de dichos tratados en la literatura producida en Historia, Geografía y Antropología en Argentina y Brasil en torno a la geografía histórica del Río de la Plata. Hemos podido reconocer un corpus de trabajos que incluyen las visiones oficiales correspondientes a los siglos XIX y XX y las perspectivas críticas a estas interpretaciones que emergen fundamentalmente a partir de la década de 1980. En particular, deseamos comprender qué visiones sobre el territorio y las fronteras ofrecen estos estudios. Nuestra aproximación nos ha llevado a diferenciar tres líneas de investigación.

La primera línea corresponde a los análisis comprendidos bajo la rúbrica de nacionalismo territorial que se perfilaron hacia finales del siglo XIX, tuvieron diferentes expresiones en el siglo XX y fueron objeto de crítica a partir de la década de 1990. La segunda pro-

2. P. Sahlins, "Natural frontiers revisited: France's boundaries since the Seventeenth century", The American Historical Review, 95, 1990, 1423-1451; F. Ratzel, La geographie politique. Les concepts fundamentaux. Paris, 1987. 
puesta emerge de los estudios de Historia de la ciencia, del arte y de la técnica. Desde este punto de vista el interés del análisis se centra en la actuación de las partidas demarcadoras que pretenden llevar al terreno las decisiones tomadas en el ámbito diplomático. La tercera perspectiva de trabajo se deriva de los estudios históricos y antropológicos emergentes desde la década de 1980 y 1990. En ellos se presenta el Río de la Plata como un ámbito con densidad histórico-social y de disputas diversas, involucrando a otros agentes como comerciantes, contrabandistas, autoridades locales, ganaderos hispano-criollos, jesuitas, y distintas parcialidades indígenas.

A continuación abordaremos aquellas perspectivas, teniendo en cuenta los trabajos que resultan más representativos de las mismas. Esta aproximación, por un lado, nos permitió identificar la abundancia, durabilidad y heterogeneidad de formas de construcción del nacionalismo territorial tanto en Argentina como en Brasil, que, en algunas coyunturas, entraron en diálogo. Por el otro nos llevó a constatar cierta sintonía en las formas de tratamiento de las temáticas agrupadas en la segunda y tercera perspectiva en la literatura de Argentina y Brasil. Ello se deriva del trabajo con marcos epistemológicos comunes que emergen en la década de 1980 y que, de alguna manera, son críticos de las visiones que sustentan la primera línea de indagación. Cabe destacar también que la lente desde la cual realizamos nuestra lectura se deriva de la reinterpretación del nacionalismo territorial que venimos llevando adelante desde nuestros estudios de Geografía Histórica y fronteras ${ }^{3}$.

Los desarrollos recientes en el ámbito anglosajón ${ }^{4}$ e hispano-franco-portugués ${ }^{5}$ respecto a las actuaciones de las poblacionales locales en la frontera, a veces, en interacción con las decisiones tomadas por los poderes monárquicos, nos permiten encontrar lagunas en la segunda y tercera perspectiva y proponer pistas para enriquecerlas.

Si bien reconocemos que los trabajos que abordan los prolegómenos, las negociaciones, y repercusiones de las firmas de los Tratados de Madrid y San Ildefonso son numerosos ${ }^{6}$, bus-

3. Zusman, op. cit.; S. Nunes Pereira, Obsessões geográficas: viagens, conflitos e saberes no âmbito da Sociedade de Geografia do Rio de Janeiro, Revista da Sociedade Brasileira de História da Ciência, 3, 2005, 112-124.

4. J. Erbig Jr., Imperial Lines, Indigenous Lands: Transforming Territorialities of the Río de la Plata, 16801805, Tesis doctoral, Universidad de Carolina del Norte, Chapel Hill, 2015; T. Herzog, Frontiers of Possession. Spain and Portugal in Europe and the Americas, Cambridge-London, 2015.

5. J. García Álvarez y J.-Y. Puyo, "La aportación geográfica y cartográfica de las Comisiones de Límites luso-franco-españolas (siglos XVIII y XIX). Apuntes para una historia comparada de conocimiento y la cooperación científica sobre la frontera., Terra Brasilis (Nova Série), 6, 2015, 1-20. En línea en: http://terrabrasilis.revues.org/1693. [consulta 28.6.2018]; J. García Álvarez y P. Puente Lozano, "Las comisiones mixtas de límites y las representaciones geográficas de la frontera hispano-portuguesa (1855-1906”). Revista de Historiografía, 23, 2015, 67-100; J. García Álvarez y P. Puente Lozano, "A controversial natural border: the making of Spanish-Portuguese boundary along the Minho River (1855-1866)". Geoforum, 2017, 79, 5-16.

6. Por ejemplo ver: M. Lucena Giraldo, "El Tratado de límites de 1750 desde la perspectiva española”, en. El tratado de Tordesillas... op.cit, 1611-1626; J. Couto "O tratado de limites de 1750 na perspectiva portuguesa”, en El tratado de Tordesillas, op.cit, 1593-1610; M. Guedes “A cartografia da delimitação das fronteiras no Brasil no século XVIII, en. Cartografia e Diplomacia no Brasil do século XVIII. Catalogo XVII Congresso 
camos realizar una relectura orientada por los puntos de partida señalados anteriormente. En este sentido nos interesa, por un lado, entender las implicancias socio-territoriales de la firma de los tratados en los procesos de formación de los Estados Nacionales y, por el otro, a reconocer las potencialidades y limitaciones ofrecidas por los estudios concebidos como paradigmáticos de las distintas perspectivas para poder reinterpretar las dinámicas territoriales pasadas en el Río de la Plata.

\section{Los estudios basados en el nacionalismo territorial}

Bajo esta denominación inscribimos aquella literatura constituida por textos de historiadores, geógrafos, geopolíticos, especialistas en relaciones internacionales y ensayistas que hicieron del territorio y de los diversos «mitos de origen territorial» un elemento clave de la construcción imaginada de los Estados ${ }^{7}$. Estos escritos buscaron otorgar una homogeneidad cultural, cuando la diversidad étnica u otro tipo de representaciones colectivas no podían garantizarla ${ }^{8}$.

A través de la historia de los Estados latinoamericanos, el territorio y distintas versiones sobre su genealogía aparecieron como dimensiones de la nación que fueron activadas en aquellos momentos en que la cohesión social parecería encontrarse amenazada.

Para la mayor parte de los trabajos que adscribimos a esta línea de investigación los Tratados de Madrid y de San Ildefonso participaron de la definición de los mitos de origen territorial de Argentina y Brasil. Esto quiere decir que ellos colaboraron a configurar los moldes naturales de ambos países, a la vez, que contribuyeron a establecer una continuidad entre el pasado colonial y el período post-independencia. Esta construcción mítica hizo caso omiso al carácter «no lineal, complejo y contradictorio de construcción de los Estados nacionales». ${ }^{9}$

En otras palabras, el pasaje del periodo colonial al Estado nacional fue mediado por conflictos y negociaciones entre las elites regionales, con las poblaciones indígenas, y por ensayos de modos de organización política y de construcciones territoriales con formas y

Internacional de História da Cartografia. Lisboa; I Guerreiro, "As demarcações segundo o Tratado de Santo Ildefonso", en Cartografia e Diplomacia no Brasil do século XVIII. Catalogo XVII Congresso Internacional de História da Cartografia. Lisboa, M. C. Ferreira, "O Mapa das Cortes e o Tratado de Madrid A cartografia a serviço da diplomacia" Varia Historia, 23 (37), 2007, 51-69. F. Camargo, "Las relaciones luso-hispánicas en torno a las Misiones Orientales del Uruguay: de los orígenes al Tratado de Madrid, 1750". Fronteras de la Historia, 8, 2003, 217-248.

7. P. Cavaleri, La restauración del Virreinato. Orígenes del nacionalismo argentino, Bernal, 2004; D. Magnoli, O corpo da pátria: imaginação geográfica e política externa no Brasil (1808-1912), São Paulo, 1997; J. Pimenta, Estado y Nación hacia el final de los imperios ibéricos. Río de la Plata y Brasil (1808-1828), Buenos Aires, 2011.

8. A.C.R. Moraes, Território e História no Brasil, São Paulo, 2005; M. Quijada, "Nación y territorio: la dimensión simbólica del espacio en la construcción nacional argentina Siglo XIX", Revista de Indias, 60, 2000, 373-394.

9. Pimenta, Estado y Nación hacia el final... op. cit., 34 
extensiones distintas de las que conocemos en la actualidad ${ }^{10}$. Los análisis realizados desde la década de 1990 ponen en cuestión dichas interpretaciones lineales, destacan que los estudios geográficos e historiográficos oficiales se ocuparon de construir mitos de origen fundamentados muchas veces en narrativas cartográficas y legitimar prácticas de expansión territorial ${ }^{11}$.

En el caso de Brasil, la idea de la «Isla-Brasil» encuentra sus orígenes en períodos previos a la emancipación política (lo cual nos lleva a hablar de un imaginario luso-brasileño) con implicaciones en los relatos territoriales post-independencia. El mito alude a la existencia de un espacio «natural» predestinado a convertirse en el territorio del Estado y a legitimar la expansión hacia el oeste a fin de encontrar su contorno definitivo. En el caso de Argentina, el relato de origen remite a la restauración del Virreinato del Rio de la Plata, unidad jurídicoadministrativa de la colonia española configurada en América Meridional en el año 1776.

En este apartado buscamos situar los tratados de límites en cuestión en las versiones historiográficas que comportan los mitos. Se trata de ver cómo estos son referenciados en los trabajos analizados. Cabe destacar que en el caso de la historiografía de Brasil son más comunes las alusiones al Tratado de Madrid que al de San Ildefonso, bajo la excusa del escaso avance de las acciones demarcatorias. Ello probablemente refleja el hecho de que el segundo supusiera para Portugal, la pérdida de aquellos territorios que habían sido asignados en ocasión de firmarse el primero. En el caso de la historiografía argentina, se alude a ambos tratados, pero la desconsideración tanto historiográfica como diplomática del Tratado de San Ildefonso por Brasil, hablaría del límite efectivo que correspondería al territorio del Virreinato del Río de la Plata y, por lo tanto, de la extensión hacia el este de los territorios pretendidos por Argentina.

\section{La «Isla-Brasil» y el expansionismo brasileño}

En relación a Brasil, dos narrativas tuvieron presencia recurrente en la historiografía: la primera, provista de argumentos fisiográficos, atribuye a una insularidad supuestamente inscrita en el continente sudamericano la cuna ancestral de la nación brasileña (mito de la «IslaBrasil»); la segunda, manteniendo los aspectos básicos de la anterior, expande la «frontera natural» de la geografía insular imaginada, actualizándola de acuerdo con los avances en la ocupación del territorio hacia el oeste (lo que llamamos «expansión hacia adentro»).

10. Para Argentina ver T. Halperin Donghi, Revolución y Guerra. Formación de una elite dirigente en la Argentina Criolla, Buenos Aires, 2014; J. C. Chiaramonte. "El federalismo argentino en la primera mitad del siglo XIX”, en M Carmagnani (coord.). Federalismos latinoamericanos: México, Brasil, Argentina. México, 1994, 81-132. Para Brasil ver I. Jancso (org.) Brasil: Formação do Estado e da Nação. São Paulo, 2003. v. 1. D Magnoli. “O Estado em Busca do seu território”. Terra Brasilis, 4-5, 2002-2003, 27-42; D. Magnoli, O corpo da patria...op.cit.

11. P. Cavaleri, La restauración del Virreinato...op.cit.; D. Magnoli, O corpo da pátria...op. cit.; J. Pimenta, Estado y Nación hacia el final de los imperios ibéricos....op. cit. L. A. Moniz Bandeira, O expansionismo brasileiro e a formacao dos Estados na Bacia do Prata. Brasilia, 1998 


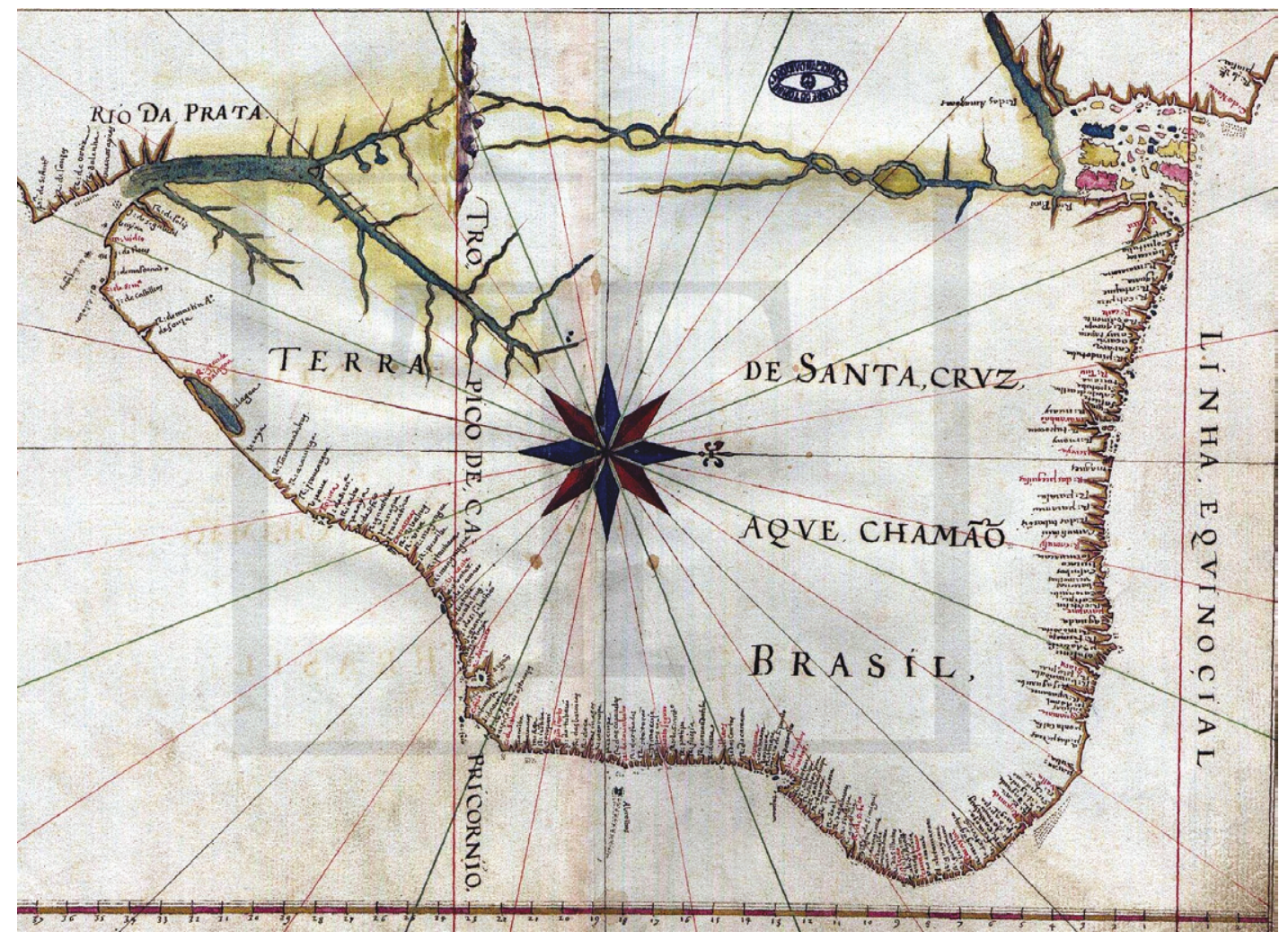

Figura 1. Mapa incluido en la Descrição de todo o marítimo da Terra de Santa Cruz chamado vulgarmente, o Brasil, de João Teixeira Albernaz, 1640. En 1501, cuando el rey Don Manuel comunicó en carta a los reyes católicos el descubrimiento de Brasil, se refirió a aquellas tierras como Tierra de Santa Cruz, nombre que sería empleado oficialmente por casi dos siglos. Sin embargo, desde 1505, el nombre Brasil también ya era usado para designar el nuevo dominio, aunque no oficialmente. Luego adquirió predominancia en documentos textuales y mapas.

El mito de origen corresponde a la creencia de que la integridad político-territorial, mantenida por el dominio portugués durante el período colonial y conservada por la nación independiente, derivaba de factores naturales. La supuesta unión de las cuencas hidrográficas del Amazonas y del Plata, de un lado, y las aguas del océano Atlántico, de otro, configuraría la «Isla-Brasil», entidad territorial separada del continente por una extensa frontera fluvial (Figura 1). De acuerdo con esta representación, presente en crónicas y en varios mapas de los siglos XVI y XVII ${ }^{12}$, el Brasil se definía como una realidad geográfica, incluso antes de la

12. En el marco de la cartografía portuguesa, véase el mapa de Bartolomeu Velho (1561); la carta América Austral de Luís Teixeira (1600); el mapa inicial de Atlas do Brasil, atribuido a João Teixeira Albernaz (1640) 


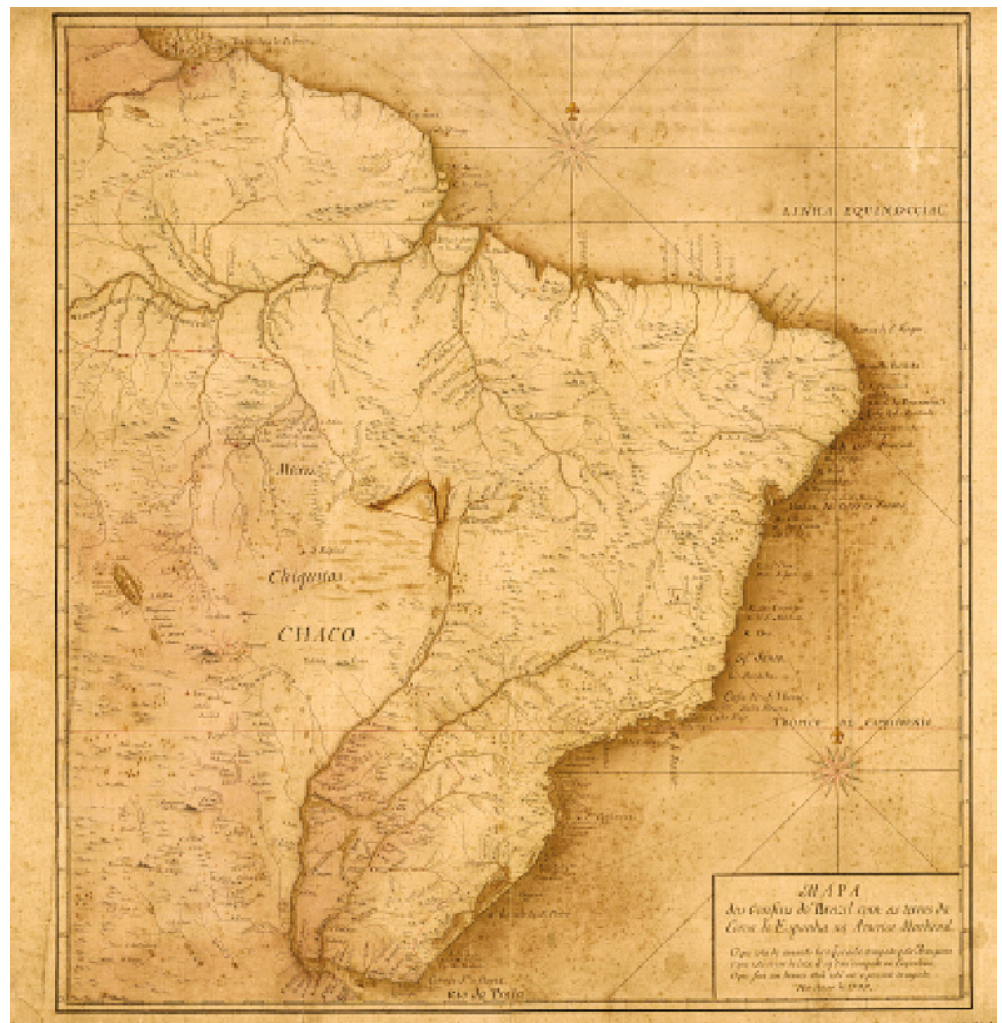

Figura 2. Mapa das Cortes ou Mapa dos confins do Brasil com as terras da coroa de Espanha na América Meridional, Alexandre Gusmão, 1749. Fuente: Archivo Digital, Biblioteca Nacional, Brasil.

colonización. Este imaginario se impregnó de la visión geopolítica de la Corona portuguesa y fue instrumentalizado por una cartografía oficial utilizada en las discusiones de límites, alcanzando su mayor expresión en el Mapa de las Cortes sobre el cual se basarían las negociaciones del Tratado de Madrid (Figura 2).

En la medida que nuestro interés aquí no reside en abordar los aspectos políticos y diplomáticos del mito, sino su dimensión historiográfica, hemos elegido identificar las líneas interpretativas con mayor resonancia en la literatura histórica y geográfica en lengua portuguesa, de rasgos nacionalistas. En la definición de tales líneas, más que versiones oficiales

y el de América do Sul, incluido en el conjunto de siete cartas elaboradas por Antônio Sanches (1641), entre otros. En la cartografía holandesa, véase Americae pars meridionalis, de Henricus Hondius (1638) y America Nova Tabula, de Willem Blaeu (1642). Ver I. Kantor, "Usos diplomáticos da Ilha-Brasil: polêmicas cartográficas e historiográficas”, Varia História, 23, 2007, 70-80. 


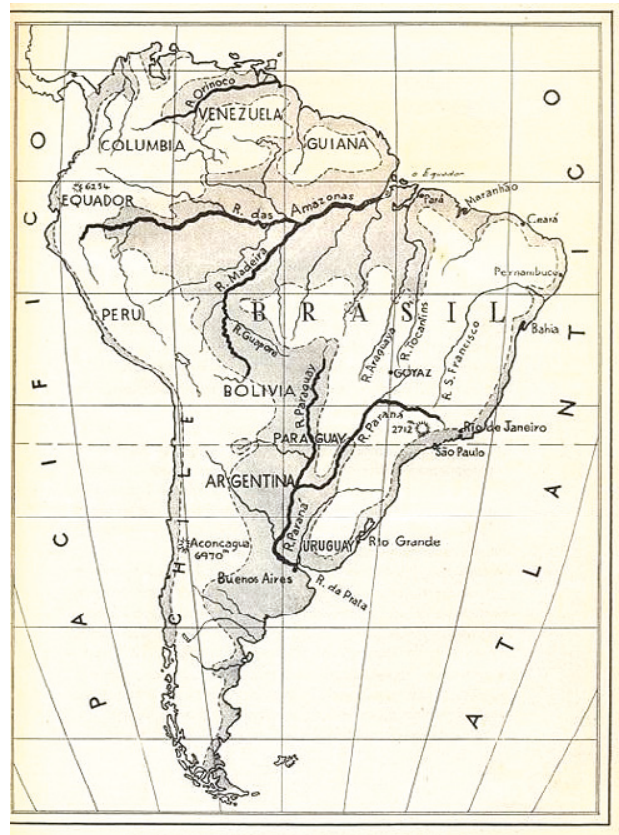

A AMERICA DO SUL-A GRANDE ILHA BRASILEIRA

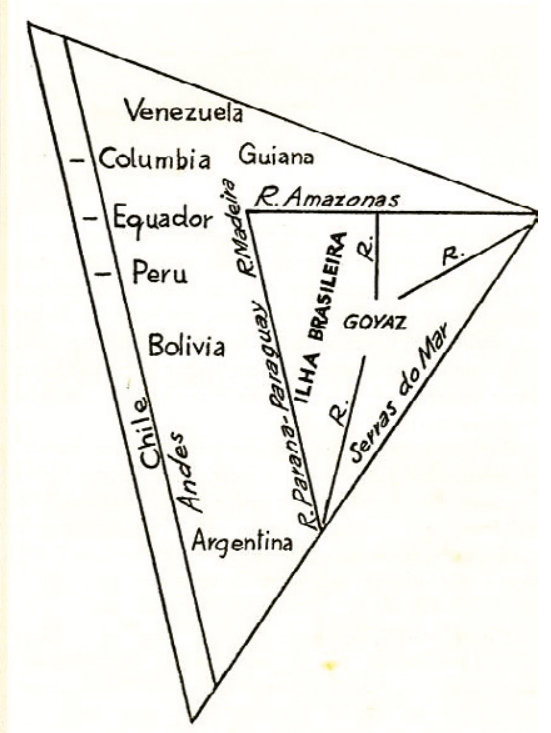

Fisionomia fundamental da América do Sul
Figura 3. Fisionomia Fundamental da América do Sul. Fuente: Jaime Batalha Reis, "A organização geográfica da América do Sul e do Brasil" (1896), en Estudos Históricos e Geográficos. Divisão de Publicações e Biblioteca. Agência Geral das Colônias, 1941.

de Estado, consideramos ciertas formulaciones arquetípicas reproducidas en ámbitos diplomáticos y militares, con gran capacidad de diseminar imaginarios geográficos. Al ofrecer un pre-figuración geográfica tanto del dominio portugués como del Estado independiente, la «Isla-Brasil» actuó como mito fundador de herencia portuguesa ${ }^{13}$. Debido a esta razón, sirvió de base para construcciones historiográficas nacionalistas, tanto en Portugal como en Brasil - en el primer caso para el rescate de un pasado glorioso y, en el segundo, para fundamentar la unidad nacional como destino.

Esta visión naturalizada y continuista de la unidad política ganaría un sentido operativo en la historiografía oficial del Segundo Imperio de Brasil. Ella sería acuñada por Francisco Varnhagen (1816-1878) ${ }^{14}$ y reproducida por el Instituto Histórico y Geográfico Brasilero a través de la publicación de diversos documentos relativos a los límites y cuestiones sobre el Plata, entre las décadas de 1860 y 1870. Con un perfil menos archivístico, la misma visión encontraría raíces profundas en la intelectualidad portuguesa hacia los finales del siglo XIX y principios del siglo XX, que también actuó en la esfera pública. El diplomático Jaime Batalha Reis (1847-1935), por ejemplo, sintetizó de forma emblemática la idea de una unidad

13. Kantor, op.cit. 76.

14. F.A.Varnhagen, Historia geral do Brazil, T. 2. Rio de Janeiro, 1857. 
geográfica que antecedía al Estado brasileño, garante de la integridad territorial mantenida después de la independencia. Al describir la posición de Brasil en América del Sur, Batalha Reis ${ }^{15}$ la considera una «obra maestra de escultura geográfica», por su fisonomía fácilmente detectable: un triángulo inscrito dentro de otro, tal como lo muestra el esquema que se propone a continuación (Figura 3).

Pero quien tuvo gran influencia en la difusión de la imagen insular fue el historiador y literato Jaime Cortesão (1884-1960). Lector de Batalha Reis, el autor se valió de un ensayo sobre las cuencas de los ríos de América del Sur, presentado por el cartógrafo brasileño Francisco Jaguaribe de Mattos ${ }^{16}$ en el III Congreso Internacional de Historia de la Ciencia, celebrado en Lisboa en $1934^{17}$. Al proponer la existencia de un «verdadero sistema de cuencas interconectadas» e incluso al marcar su singularidad ${ }^{18}$ el ensayo no podría ser más conveniente para la formulación de Cortesão ${ }^{19}$ elevada a la «razón geográfica Estado» $\mathrm{y}$ «pivote del expansionismo luso».

Cortesão se radicó en Brasil en el año 1940 y, a través de dos décadas, se desempeñó como docente en el Ministerio de Relaciones Exteriores dictando cursos sobre la historia de la cartografía y la formación territorial de Brasil. No sería exagerado afirmar que sus clases moldearon el pensamiento de toda una generación de diplomáticos brasileños; de modo más amplio, algunas de sus obras definieron las líneas maestras de una historiografía nacionalista luso-brasileña ${ }^{20}$. La interpretación sobre las implicaciones del Tratado de Madrid ocupaba un lugar central en esta narrativa. No por casualidad, el escritor dedicó una obra de gran aliente al negociador portugués de límites, Alexandre de Gusmão ${ }^{21}$.

Otra interpretación de Cortesão ${ }^{22}$ llevó a vincular la «Isla-Brasil» al movimiento expansionista de las bandeiras (expediciones llevadas adelante al interior de Brasil en busca de riquezas y captura de indígenas). Si bien estas ya poseían su propia narrativa mítica, ésta fue actualizada en el marco del Estado Nuevo (1938-1945), coyuntura en la que se promo-

15. J.Batalha Reis, "A Organização Geográfica da América do Sul e do Brasil”, Estudos Históricos e Geográficos, 217, 1941, $1^{\text {era }}$ edición 1896.

16. El capitán Jaguaribe de Mattos dirigía el Servicio de Finalización de la Carta de Mato Grosso, vinculado a la Comisión de Líneas Telegráficas y Estratégicas del Mato Grosso al Amazonas (conocida como “Comisión Rondon", por llevar el nombre de su jefe, Cândido Mariano Rondon). En tal condición, Jaguaribe compiló un vasto material cartográfico en Brasil y en el extranjero.

17. F. R. Oliveira, “A 'Ilha Brasil' de Jaime Cortesão: ideias geográficas e expressão cartográfica de um conceito geopolítico”. Biblio3W. Revista Bibliográfica de Geografía y Ciencias Sociales,1.191, 2017,17. En línea en: http://www.ub.edu/geocrit/b3w-1191.pdf [consulta 28.6.2018].

18. F. Mattos, citado en Oliveira. “A 'Ilha Brasil' de Jaime Cortesão”, op.cit, 18.

19. J. Cortesão, Alexandre de Gusmão e o Tratado de Madrid, 2T., Rio de Janeiro, 1950.

20. Cortesão, Alexandre de Gusmão, op.cit; J. Cortesão, Raposo Tavares e a formação territorial do Brasil. Rio de Janeiro, 1958; J. Cortesão, História do Brasil nos velhos mapas, T. II, Rio de Janeiro, 1971.

21. Cortesão, Alexandre de Gusmão, op.cit.

22. Cortesão, Raposo Tavares, op.cit. 
vió la llamada «Marcha hacia el Oeste» ${ }^{23}$. La innovación del Cortesão residió unir ambos mitos, al proponer que, en la medida que las bandeiras habrían alcanzado el Alto Paraguay, habrían restaurado la moldura deseada para recuperar el criterio de fronteras naturales. Frente a las "pérdidas de territorios» hacia el sur, a partir de la firma de los tratados, las fronteras se dilataban hacia el oeste, ampliándose la «Isla-Brasil». A partir de recuperar la formulación ancestral, la proposición creaba un nuevo mito territorial que supone la expansión «hacia adentro», una vez que - según esta visión- se lleva adelante en un espacio legítimamente incorporado al territorio de Brasil.

Dentro de la rúbrica del nacionalismo territorial brasileño, es posible reconocer también una literatura militar y geopolítica que recurre a los tratados firmados por las Coronas Ibéricas para otorgar legitimidad a las fronteras naturales y a los nuevos proyectos territoriales. En este perfil se encuadra el libro del Teniente Coronel Nery da Fonseca (1935), Fronteiras do Setor Sul (1935) En dos volúmenes el trabajo aborda de forma monográfica la cuestión de los límites meridionales de los dominios portugueses. El mismo se inicia con la bula papal de 1493 y finaliza con la independencia de las repúblicas de la Plata. La mayor parte del contenido está compuesto por anexos que incluyen los principales documentos referentes al tema, transcritos íntegramente; el resto del texto se compone de comentarios que justifican las posiciones portuguesas frente a las españolas o que defienden las posiciones portuguesas frente a la crítica que realizan los libros de historiadores jesuitas contemporáneos al autor ${ }^{24}$.

Por su parte, el diplomático y escritor Renato Mendonça denominó a su trabajo Fronteira em Marcha (una alusión explícita al movimento expansionista) ${ }^{25}$. El Tratado de Madrid adquiere un papel destacado en la primera parte del ensayo ya que actúa como base histórico-jurídica para legitimar la expansión territorial de lo que sería Brasil; no por casualidad, la segunda parte del texto lleva en su título la expresión "Proyección Continental" (del Imperio Brasileño) y trata básicamente de la geopolítica del Plata a mediados del siglo XIX. Cabe destacar que esta idea, tomada de Mario Travassos ${ }^{26}$, remite a un área de importancia estratégica localizada en el interior de América del Sur, que demandaba esfuerzos del gobierno brasileño (construcción de vías de comunicación) para intentar neutralizar el control de la cuenca del Plata por parte de Argentina. Desde la perspectiva interpretativa de Mendonça y, a partir del contexto histórico que analiza, tales esfuerzos son llevados a otro plano, alcanzando el límite de la confrontación bélica, y a veces, transgrediéndolo. Planteada la cuestión de esta manera, resulta difícil conciliar el leitmotiv de Travassos con la idea de «expansión hacia dentro». Al final, ¿dónde residía la frontera? Para Mendonça, ciertamente no sería aquella dibujada en

23. La Marcha hacia el Oeste fue una política territorial que mezcló una retórica de incentivo a la ocupación con medidas concretas de colonización del interior brasileño llevadas adelante en el período señalado. Ver. C Ricardo, Marcha para Oeste. Rio de Janeiro, 1970, primera edición 1940.

24. N. da Fonseca, Fronteiras do Setor Sul. Rio de Janeiro, 1935

25. R. Mendonça, Fronteira em Marcha. Ensaio de Geopolítica Brasileira, Rio de Janeiro,1956.

26. Mario Travassos (1891-1973) se encuentra entre los autores que introdujeron los estudios geopolíticos en Brasil. Sobre la base del concepto de heartland propuesto por Halford Mackinder, Travassos escribió Aspectos Geográficos Sul-Americanos, São Paulo, 1931. La 2da edición (ampliada) publicada en 1935 se tituló Projeção Continental do Brasil. 
San Ildefonso: «Brasil no podría aceptar como definitiva la frontera del Tratado preliminar de 1777, el cual, según la hermenéutica jurídica, era por naturaleza un tratado provisional y destinado (...) a servir de base a otro, que no se llegó a hacer ${ }^{27}$. Según el autor, se trataba de una geopolítica que orientaba al gobierno brasileño en la destrucción de un intolerable objetivo político argentino: la restauración del Virreinato del Plata. Dentro de esa lógica, el expansionismo brasileño encontraba una justificación defensiva.

\section{La restauración del Virreinato del Río de la Plata y la creación de su imagen cartográfica}

El Virreinato del Rio se configuró como una unidad jurídico administrativa del Imperio Español durante el reinado de Carlos III en el marco de las reformas borbónicas. En el proceso de la constitución del Estado Argentino, la reconstrucción del Virreinato se tornó un «gran objetivo histórico de la política exterior argentina, (...) transmitidos a otros historiadores argentinos y llegaron a introducirse en los manuales escolares de historia y geografía, atlas históricos y ensayos de geopolítica e historia diplomática» ${ }^{28}$. Las diferencias entre la supuesta extensión de esta unidad jurídica administrativa del Imperio Español y las formas que fue adquiriendo el territorio argentino, a partir de las negociaciones diplomáticas con los países que se configuraron de modo simultáneo como Brasil, Chile, Uruguay, Paraguay o Bolivia, fueron interpretadas por los hacedores del Estado en términos de pérdidas territoriales. Los Tratados de Madrid y San Ildefonso fueron incorporados en el tejido de las argumentaciones sobre los motivos que justificaban las pérdidas. Mientras que el primero era leído como una legitimación del avance portugués en los territorios de América Meridional, el segundo era presentado como la expresión de las posesiones que habrían tenido que quedar bajo dominio argentino en el Río de la Plata.

Cabe destacar también que la no coincidencia entre la forma y extensión del territorio de Argentina con aquellos correspondientes al Virreinato del Río de la Plata ponía en cuestión las bases de la nación, que desde la perspectiva de muchos escritores, políticos y diplomáticos del período pre-existiría al Estado.

Para Cavaleri, la restauración del Virreinato pasó a ser reivindicada por los seguidores de la obra historiográfica y política del presidente Bartolomé Mitre (1862-1868) y recobrada en la década de 1880 por Vicente Quesada, jurista y representante diplomático en diversos países, entre ellos Brasil donde fue designado para contribuir a la resolución del conflicto Misiones/de Palmas (1883-1885).

De hecho, la relación entre los Tratados de Madrid y San Ildefonso y la restauración del Virreinato se hace explícita a partir de dicho conflicto. Este altercado tuvo su base en la confusión que mostraron los propios demarcadores coloniales respecto los ríos que recibían el nombre de Pequirí o Pepirí-guazú y San Antonio. La resolución del diferendo no tuvo

27. Mendonça, op.cit. 135.

28. Cavaleri, op.cit 12. 
lugar durante la misión de Quesada sino a través del fallo del presidente de Estados Unidos, Stephen Grovenor Cleveland en 1895 que dejó gran parte del área en conflicto bajo dominio de Brasil. Sobre la base del mito de la restauración del Virreinato del Río de la Plata algunos diplomáticos, como Ernesto Quesada, hijo de Vicente Quesada, leyeron el resultado del arbitraje como una muestra de los procesos de segregación del territorio argentino ${ }^{29}$.

Cabe destacar que el mito de origen no solo se recreó historiográfica sino cartográficamente. De hecho en este período aparecen las primeras representaciones visuales que dan cuenta de la forma y extensión de un Virreinato «deseado», pues resulta difícil identificar representaciones correspondientes al período colonial que buscasen diferenciar las posesiones al interior de la propia Corona, observándose fundamentalmente la tendencia a representar las tierras que quedaban en manos de distintas potencias coloniales ${ }^{30}$. El Virreinato del Río de la Plata fue concebido textualmente por la Real Cédula de agosto de 1776 como una unidad que se extendía desde el Alto Perú hasta la Patagonia y desde el litoral Atlántico hasta la Cordillera de los Andes. Entre las representaciones diseñadas en el proceso de formación del Estado Nación, podemos hacer mención a aquella incluida en el Atlas Histórico de la República Argentina editado por el militar, periodista y escritor Juan José Biedma en el año 1909. En este Atlas de carácter pedagógico, la imagen del Virreinato estaría inspirada en un «mapa del siglo XVII» no identificado por el propio autor (Figura 4). En esta imagen figuran las intendencias en las que se dividía el Virreinato, siguiendo la Real Ordenanza de Intendentes de 1784. Las vicisitudes que se vivencian en América Meridional entre los años de 1776 y 1810 (período a cual correspondería el mapa en cuestión) no son incorporadas en la representación, de modo tal que las Misiones Guaraníes (objeto de conflicto entre España y Portugal) se incluyeron como parte de dominio español. Además, el límite oriental del Virreinato, en el área del Río de la Plata, siguió el criterio definido en el Tratado de San Ildefonso. A ello se sumó la inclusión efectiva al Virreinato de los territorios bajo dominio indígena (como la Patagonia).

Cabe destacar también que el propio Atlas publicado por Biedma incluye un mapa de Pedro Cevallos, quien fuera gobernador de Buenos Aires y primer Virrey del Virreinato del Río de la Plata, que acompañó a su documento crítico del Tratado de Madrid pues consideraba que este legitimaba el avance «abusivo» realizado por los portugueses en relación con la línea de Tordesillas (Figura 5). El diálogo entre esta representación cartográfica y aquella del Virreinato que definió el límite intercolonial a partir del Tratado de San Ildefonso habla del interes de Biedma por difundir una imagen que permitiera legitimar las pretensiones argentinas en el área de Misiones/de Palmas y reconocer la «pérdida territorial» que afectó al país.

Luego de este período inicial de configuración del mito de restauración del Virreinato del Río de la Plata, este es recreado en dos momentos posteriores por la historiografía y

29. Pablo Buchbinder . Los Quesada. Letras, ciencia y política en la Argentina 1850-1934., Buenos Aires, 2012.

30. Ver al respecto Mapa geográfico de la mayor parte de la América Meridional que contiene los paises por donde debe trazarse la línia divisoria que divida los dominios de España y Portugal elaborado por el Teniente General Dn Francisco Requena en el año 1796. 


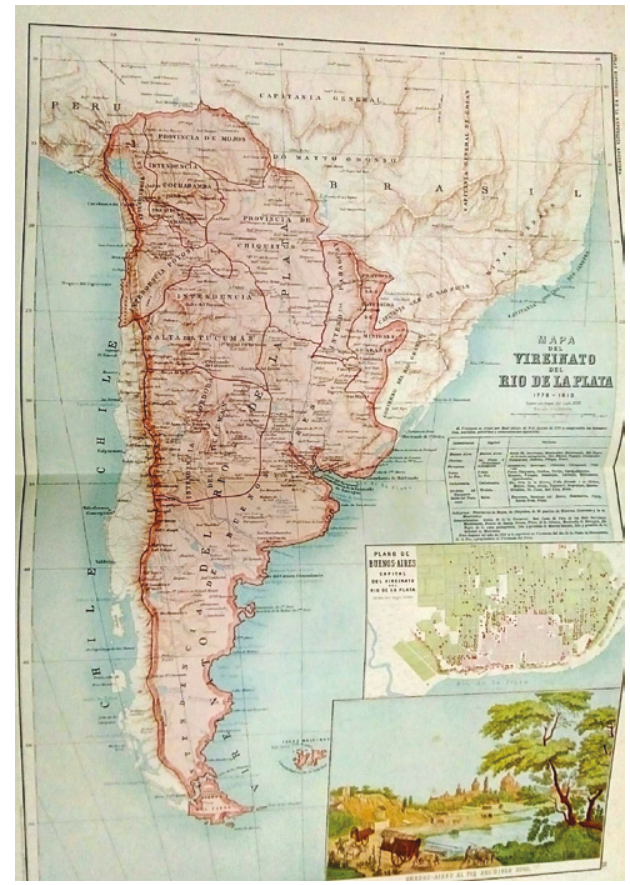

Figura 4. J. J. Biedma, Virreinato del Rio de la Plata. En: Atlas histórico de la República Argentina, Buenos Aires, 1909.

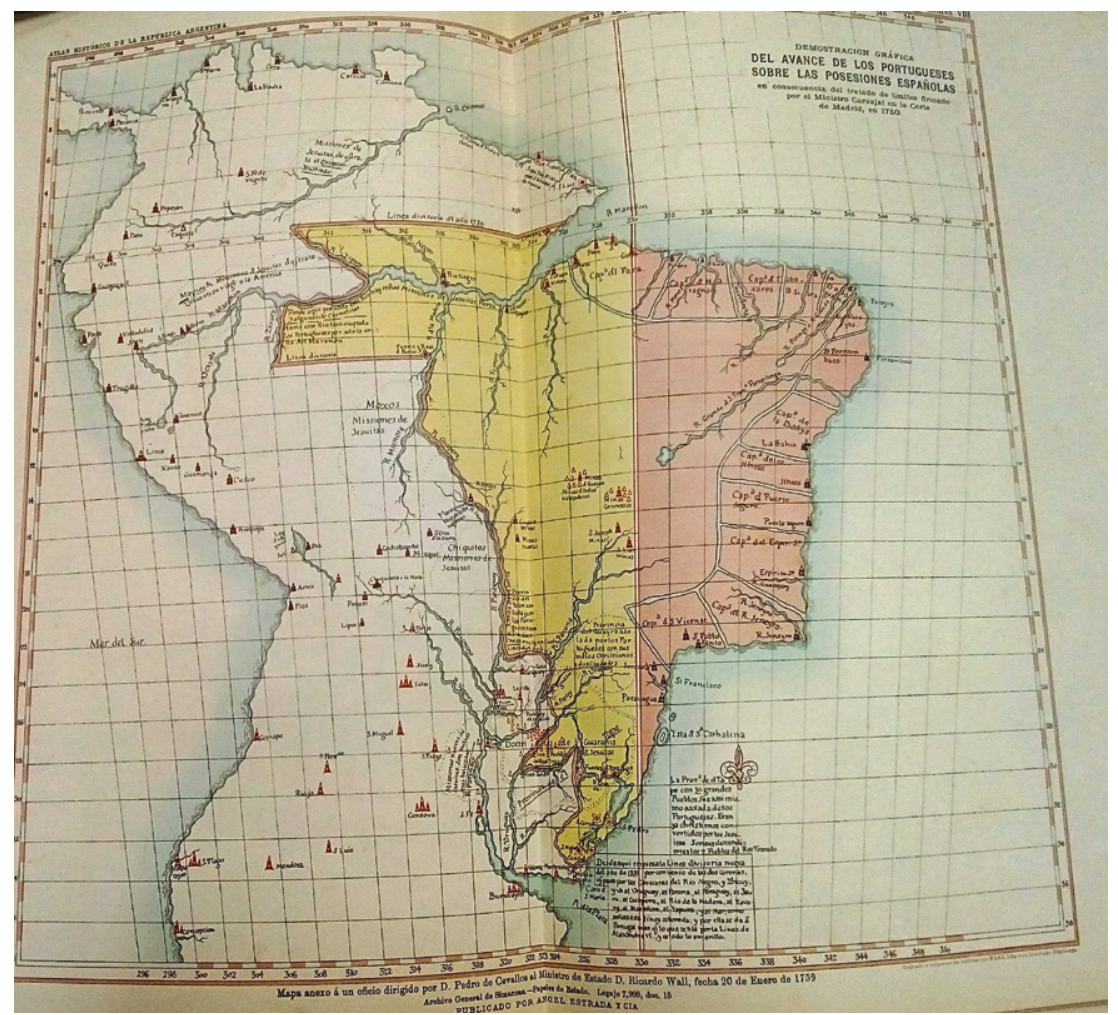

Figura 5. P. Cevallos. Demostración gráfica del avance de los portugueses sobre las posesiones españolas en consecuencia del Tratado de Límites firmado por el Ministro Carbajal en la Carta de Madrid de 1750. En: J.J. Biedma, Atlas histórico de la Republica Argentina, Buenos Aires, 1909. 
geografía nacional. El primer momento está en directa relación con las posturas de la década de 1930 de «recrear los mitos fundadores, producir nuevas interpretaciones, inventar otras matrices simbólicas» ${ }^{31}$. En este contexto es posible identificar las contribuciones de la autodenominada Nueva Escuela Histórica, destacándose entre sus miembros Ricardo Levene (1885-1959), Emilio Ravignani (1886-1954), Enrique de Gandía (1906-2000) y Ricardo Caillet Bois (1903-1977). Desde la perspectiva de estos historiadores, en la medida que la nación preexistía a la constitución del Estado, la territorialidad adquiría un papel clave en su esencialización y naturalización. En este marco, «la unión entre las provincias, que hasta 1810 constituían el Virreinato del Rio de la Plata (configuraban) partes inexorablemente destinadas a formar la nación argentina ${ }^{32}$. A partir de esta constatación, los historiadores se dedicaron a revisar los conflictos limítrofes en los que Argentina se vio envuelta y la forma en que diplomáticos y políticos se enfrentaron a ellos a fines de evaluar su actuación frente al objetivo de restaurar el Virreinato ${ }^{33}$. De estas visiones derivan dos representaciones del Virreinato del Río de la Plata publicadas en dos textos de carácter enciclopédico de relevancia del período. Así aquella producida por Emilio Ravignani aparece en el volumen IV dedicado a la formación de dicha unidad jurídica administrativa de la obrada editada por Ricardo Levene, Historia de Nación Argentina: desde los orígenes hasta la organización definitiva en 1862) (1936-1950) ${ }^{34}$. Por otro lado, aquella diseñada por Ricardo Caillet Bois es incorporada en el compendio editado por los geógrafos Francisco de Aparicio y Horacio Difrieri, Argentina. Suma de la Geografia (1958) en su capítulo dedicado a «La Formación del Estado» (vol I) ${ }^{35}$. Ambos mapas retoman la definición del límite entre las posesiones españolas y portuguesas en el Río de la Plata establecido por el Tratado de San Ildefonso. A la vez, y a diferencia del mapa de Biedma reconocen la existencia de poblaciones indígenas en la zona de la Pampa y del Chaco, no así en el área patagónica.

El segundo momento de restauración del mito del Virreinato corresponde al período de la Guerra Fría, de la difusión de la doctrina de la Seguridad Nacional y de la instauración de la dictadura militar en Argentina (1976-1984). Frente a los conflictos económicos y sociales, y en el marco de una fuerte represión social, el gobierno de facto encontró en el nacionalismo territorial un elemento de cohesión social. Se concebía que muchos de los problemas que se identificaban en el país (como el ingreso del marxismo en el campo académico y polí-

31. M. Svampa, El dilema argentino. Civilización o Barbarie. Buenos Aires, 1994.

32. Pimenta, op. cit. 38.

33. Para Caillet Bois la política exterior argentina se habría caracterizado por una serie de debilidades. Estas se expresarían en el escaso conocimientos tanto de los terrenos disputados como de los antecedentes históricos, en la falta de formación de sus diplomáticos, en la carencia de objetivos precisos en la política exterior y en la priorización de las preocupaciones políticas propias por sobre aquellas que tienen que ver con el interés general. Ver Cavaleri, op.cit. 160.

34. E. Ravignani, “El Virreinato del Río de la Plata (1776-1810)”, en Ricardo Levene (Dir.), Historia de la Nación Argentina, Buenos Aires, Vol IX, 1939.

35. R. Callet Bois, "La formación del Estado Argentino", en F. Aparicio y F. Difrieri, Argentina. Suma de Geografia, Vol VIII, 1960, 11-13. 


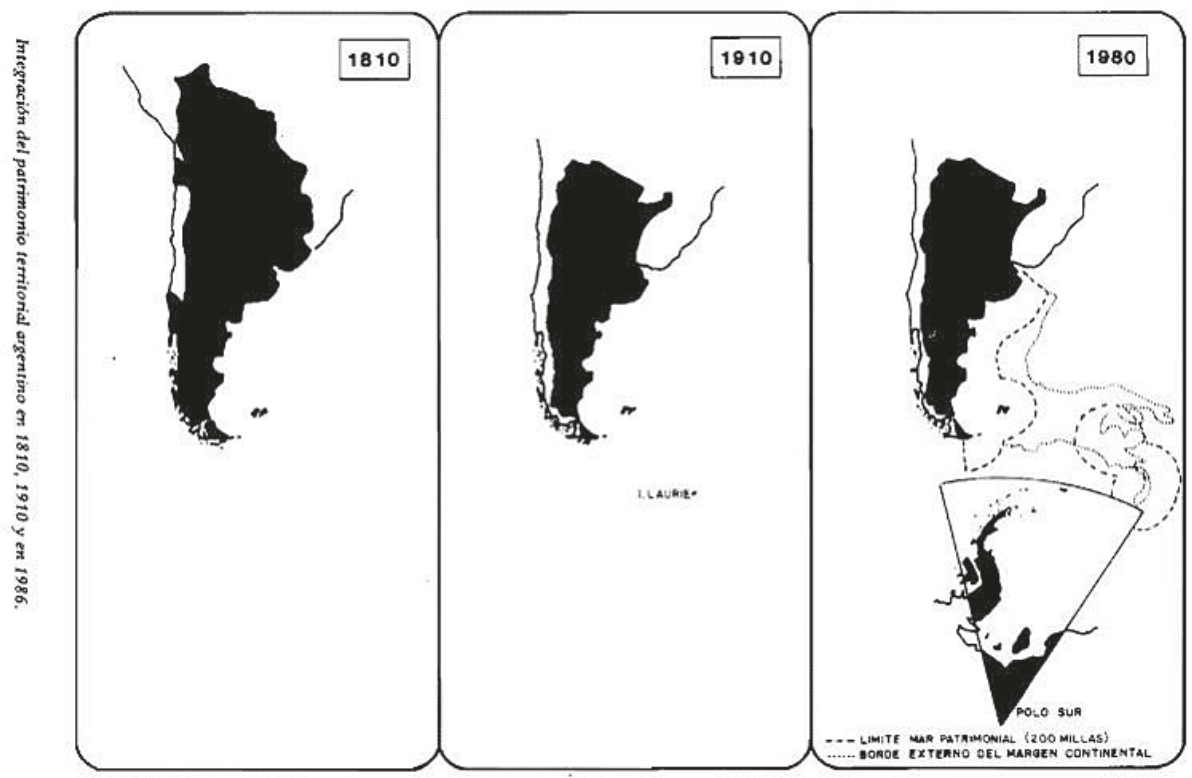

Figura 6. R. Rey Balmaceda y G. De Marco. Integración del Patrimonio Territorial. En J. Roccatagliata, Juan (coord.) La Argentina. Geografía general y los marcos regionales. Buenos Aires, 1992, 25-70.

tico) se debían a la falta de «conciencia territorial» ${ }^{36}$. El mito del Virreinato del Rio de la Plata es nuevamente evocado en el marco del relato cartográfico elaborado por el geógrafo Raúl Rey Balmaceda y Graciela De Marco ${ }^{37}$ (Figura 6). En esta narrativa la historia del territorio argentino está signada por tres fechas: 1810, 1910 y 1980. Mientras que el territorio del Virreinato es asociado con aquel correspondiente al momento de la independencia 1810 (se homologa el territorio del Virreinato con aquel que correspondería a la nueva unidad política: las Provincias Unidas del Río de la Plata o Provincias Unidas de América del Sud), el mapa correspondiente al año 1910 era identificado como aquel perteneciente al momento en que se habían finalizado las tareas de definir los límites del país. La comparación entre el mapa de 1810 y el de 1910 invitaba a identificar los procesos de «desmembramiento» a los cuales habría quedado «sometido el territorio» argentino. Sin embargo, la extensión que poseía el país en 1980 con la incorporación cartográfica de la plataforma submarina, la Antártida Ar-

36. L.G. Rodríguez, "La noción de frontera en el pensamiento geográfico de 1970 y 1980 en Argentina". Cuaderno de Geografía. Revista Colombiana de Geografía, 23, 2014, 107-119.

37. R. Rey Balmaceda y G. De Marco. “Conformación del sistema político territorial”, en J. Roccatagliata, (coord.) La Argentina. Geografía general y los marcos regionales, Buenos Aires, 1992, 25-70. 
gentina y las Islas del Atlántico sur ${ }^{38}$, aseguraba, en términos ratzelianos el poder del Estado Nación y la «integración del patrimonio». Un poder que podría ser puesto en cuestión por las hipótesis de conflicto con Brasil (en torno a Itaipú), con Chile (en relación al Beagle) y con Inglaterra (en relación a Malvinas) y que el gobierno militar se ocupó de realzar a los fines de alcanzar su legitimidad social, como lo demostró la guerra de Malvinas de 1982.

En síntesis, el Virreinato reconstruido pasó a ser un fantasma que se agitaba ante los países vecinos, por sobre todo frente a Brasil no solo en momento de formación del Estado Argentino, como sostiene Cavaleri ${ }^{39}$, sino también en coyunturas posteriores. En este marco, resurgían las controversias sobre las implicancias Tratados de Madrid y de San Ildefonso en el diseño territorial del país.

\section{Las propuestas asociadas a los estudios de Historia de la Ciencia, del Arte y de la Técnica}

Desde esta perspectiva el interés del análisis se centra en la actuación de las partidas demarcadoras que pretenden llevar al terreno las decisiones tomadas en el ámbito diplomático. El énfasis es puesto en la identificación de saberes, prácticas, instrumentos y representaciones visuales que contribuyeron al desarrollo de las tareas astronómicas y topográficas. Se destaca que, a través de estas técnicas e instrumentos, se esperaba traducir a términos matemáticos la configuración del terreno. A su vez, mediante este nivel abstracción se pretendía garantizar la perdurabilidad de la línea divisoria intercolonial.

Los trabajos que consideramos más representativos de esta perspectiva son el de Marta Penhos (2005) Ver, conocer, dominar: imágenes de Sudamérica a fines del siglo XVIII, y el de Heloisa Gesteira (2014) Um observatório astronômico nos confins da América Portuguesa (1750-1760). Ellos señalan que las acciones demarcadoras se acompañaron de otras de carácter exploratorio que permitieron conocer áreas hasta entonces no apropiadas por las Coronas y ponerlas en valor en términos científicos y económicos. El resultado de esta acumulación de funciones es la formación de una agenda de trabajo compleja en que los objetivos iniciales de las expediciones, relacionados a los imperativos de demarcación de límites, pasan a convivir con otros, forjados a partir de intereses y curiosidades científicas relativamente aleatorios respecto de las metas establecidas ${ }^{40}$.

38. En relación a la incorporación de estos elementos al territorio argentino ver C. Lois, "La patria es una e indivisible. Los modos de narrar la historia territorial argentina”, Terra Brasilis, 1, 2012, 1-29. En línea en: https://journals.openedition.org/terrabrasilis/138 [consulta 28.6.2018].

39. Cavaleri, op.cit. 172.

40. Otros trabajos que han abordado esta cuestión en la historiografía brasilera y argentina respectivamente son M.F. Costa, "Miguel Ciera: um demarcador de limites no interior sul-americano". Anais do Museu Paulista, 17 (2), 2009, 189-214; R.F. Figueroa, "En los márgenes del Imperio Español y de la Historia Natural: Feliz da Azara colector (1787-1789)”. Prohistoria, 15, 2011. En línea. http://www.scielo.org.ar/pdf/ prohist/v15/v15a01.pdf [consulta 28.2.2019]. 
El trabajo de Marta Penhos ${ }^{41}$ se enmarca en el campo de la historia del arte, y, como tal, presenta especial sensibilidad respecto a las representaciones construidas sobre las regiones del continente exploradas, en las que se entrecruzan registros textuales, cartográficos y pictóricos. Penhos aborda las prácticas de «ver y conocer» relacionadas con los viajes de Félix de Azara y Diego de Alvear como miembros de la partida demarcadora española destinada a definir la frontera siguiendo los postulados del Tratado de San Ildefonso. Como señala la autora, «la llamada Expedición de América Meridional excedió ampliamente sus objetivos primeros, originando una masa de informaciones sobre los territorios examinados, de la que hay testimonio en textos e imágenes ${ }^{42}$. La actividad del naturalista Félix de Azara en el área del Río de la Plata entre 1782 y 1801, la lleva a reconocer que el factor clave de su relato es la visualidad. El registro visual en forma de grabado asume un papel importante en este proceso. De ahí que los escritos de Azara sean acompañados de forma abundante por imágenes sobre la fauna de la región (sobre todo mamíferos y aves), contribuyendo a la construcción de un imaginario europeo sobre América en un momento en que ganaba cuerpo el mercado editorial reglado por la literatura de viaje.

Los veinte años de permanencia en la región y las numerosas situaciones de interrupción o los problemas surgidos en la realización de la actividad cartográfica, permitieron a Azara y a sus colaboradores reunir un copioso material en diversas áreas del conocimiento, destacándose en particular sus contribuciones a la historia natural. De hecho, a través de sus hallazgos, Azara perseguía aportar al desarrollo del proyecto de la Ilustración española de incluir la flora y la fauna americanas en una Historia Natural «universal», tal como lo preconizaba Linneo ${ }^{43}$.

Otra obra que toma en cuenta la extrapolación científica de las actividades de demarcación de los tratados de límites firmados por las Coronas Ibéricas es la de Heloisa Gesteira (2014) titulada Um observatório astronômico nos confins da América Portuguesa (1750-1760). Al relatar el viaje del navío Lampadoza al Plata, con miras de asegurar a los demarcadores lusos del Tratado de Madrid las condiciones técnicas y materiales para la realización de sus tareas, la autora proporciona evidencias suficientes para asegurar que otras motivaciones, aparte de las cuestiones de límites, dejaron también su impronta en la expedición. Su hipótesis está anclada en investigaciones ya sedimentadas en el campo de la historia de la ciencia y la tecnología $a^{44}$, según la cual los portugueses ilustrados que viajaban en nombre de Portugal «formaban parte de las redes e instituciones científicas de la época, mucho antes de las reformas pombalinas» ${ }^{45}$.

41. M. Penhos, Ver, conocer, dominar. Imágenes de Sudamérica a fines del Siglo XVIII, Buenos Aires, 2005. 42. Penhos, op.cit. 126.

43. Penhos, op.cit. 139.

44. R. Carvalho, Coletânea de Estudos Históricos (1953-1994): cultura e actividades científicas em Portugal Évora, 1997; A. Domingues, "Para um melhor conhecimento dos domínios coloniais: a constituição de redes de informação no Império português em finais do Setecentos". Manguinhos - História, Ciência e Saúde, 8, Suplemento, 2001, 823-838.

45. H. Gesteira, "Um observatório astronômico nos confins da América Portuguesa-1750-1790". En: Formas do Império. Ciência, tecnologia e política em Portugal e no Brasil. Séculos XVI ao XIX, São Paulo, 2014, 95. 
La originalidad de la visión de Gesteira reside en que las fuentes principales para desarrollar su argumentación las constituyen los instrumentos científicos -y, de forma más genérica, los materiales acarreados en el viaje. De esta manera, la autora examina atentamente la lista de objetos inventariados. Estos incluyen tanto equipamientos indispensables a los trabajos demarcatorios (teodolito, reloj solar, brújula, cuadrantes, compases, reglas, grafómetro, plancheta, etc.), como otros cuyo uso no estaba claramente asociado a actividades topográficas o cartográficas (telescopio, microscopio, barómetro, termómetro, cuadernos de dibujo y pinceles). Además de tablas astronómicas y manuales para uso de instrumentos matemáticos, entre los libros embarcados constaban ensayos de astronomía y física, tratados de perspectiva y libros dedicados específicamente a técnicas pictóricas.

Sin embargo, según Gesteira ${ }^{46}$ no bastaría con examinar el «equipaje del trazado» bajo pena de reducir el ejercicio historiográfico a la lectura e interpretación de un listado. De ahí que la autora se preocupe tanto por incorporar en su investigación las Instrucciones sobre el uso de los equipos como las vicisitudes relacionadas a su empleo en el terreno, registradas en los Diarios de la expedición. A partir del estudio de los relatos de primera partida portuguesa enviada a la región, el trabajo trae a la luz la demanda de información sobre las áreas donde la línea era demarcada, que deberían ser conocidas: sus habitantes, fauna, flora y accidentes geográficos principales. Sin embargo, los documentos no revelan solo un simple inventario de territorios que se pretendía incorporar, sino que también dan cuenta de la implicación de los astrónomos y geógrafos en funciones más específicas como el estudio acerca de la forma exacta de la Tierra, tema que suscitaba grandes discusiones en el período en Europa.

El perfeccionamiento de los procesos de medición de la Tierra y las evaluaciones más confiables sobre su formato, debidas, en gran parte, a los estudios realizados en los observatorios astronómicos de París y Greenwich, también fueron tributarios de observaciones realizadas en regiones «remotas» como los confines de América meridional donde tuvieron lugar las partidas. Para la ejecución de estas tareas, eran necesarios instrumentos precisos pero también portátiles, como aquellos que eran transportados en el viaje (como el cuarto del círculo). La simple organización de un «observatorio móvil», como señala la autora, ya ofrece indicios de las redes de colaboración entre los demarcadores portugueses que operaban dichos instrumentos y los centros que los fabricaban y que los estaban testeando.

Frente a la perspectiva anteriormente analizada que señalaba la naturalización del territorio en el marco de la definición de los mitos de origen en Argentina y Brasil, los estudios desarrollados en el campo de la historia de la ciencia, del arte y de la técnica han enfatizado el proceso de construcción territorial en el que se involucraron las partidas demarcadoras, aportando, a la vez, conocimientos a las redes científicas internacionales ya existentes en la época.

A pesar de los méritos que pueden ser acreditados a esta postura podemos identificar en ella algunas lagunas historiográficas que merecen un mayor desarrollo. Una de ellas, y quizás las más importante, es el escaso protagonismo atribuido a los nativos en la producción del conocimiento. Las operaciones llevadas a cabo por los demarcadores y sus condiciones

46. Gesteira, op.cit. 101. 
básicas de realización no podrían realizarse sin algún tipo de cooperación de las poblaciones locales, de quienes los europeos dependían para la obtención de informaciones geográficas, para el desplazamiento en el terreno e incluso para la subsistencia. Así, los primeros habrían desempeñado un papel más activo en el proceso de demarcación y mapeo de lo que es reconocido por esta historiografía. De modo complementario a este vacío, no sería exagerado suponer que los imaginarios geográficos europeos y nativos, aunque enteramente distintos, fueron forzados a coexistir e interactuar en las zonas de contacto, generando formas híbridas de representación espacial. Tales consideraciones, ausentes en los trabajos comentados, fueron planteadas en estudios recientes producidos fuera del corpus delimitado en el ámbito de este artículo ${ }^{47}$ pero que conviene ahora señalar.

\section{Estudios históricos y antropológicos que dan cuenta de la densidad histórico-social del ámbito del Río de la Plata}

En los trabajos incluidos en esta sección se presenta el Río de la Plata como un ámbito con densidad histórico-social donde tienen lugar disputas diversas que involucran a otros actores, además de aquellos que representan a las posiciones de las metrópolis ibéricas. En torno a las relaciones inestables entre la Corona de España y Portugal se van posicionando comerciantes, contrabandistas ${ }^{48}$, autoridades locales, ganaderos hispano-criollos, jesuitas, y distintas parcialidades indígenas.

La literatura que inscribimos en este apartado toma en cuenta la construcción de territorialidades por parte de las poblaciones indígenas y su interacción con actores locales (gobernadores, comerciantes, contrabandistas) y con las decisiones de las metrópolis. Como decíamos al inicio del artículo, los Tratados en cuestión procuraron someter y controlar a los grupos nativos, aunque encontraron resistencias en los sectores sociales involucrados.

A partir de la lectura a contrapelo de las fuentes coloniales, jesuíticas y de cartas indígenas es posible analizar las actuaciones económicas, políticas y bélicas de los indígenas asentados en el alto Paraná y Uruguay (Figura 7). Así se observa que las poblaciones nativas configuraban sus modos de vida estableciendo intercambios, sellando alianzas, negociando, adoptando elementos culturales de los europeos o resistiendo los procesos de relocalización compulsoria. Trabajos paradigmáticos como los de Lía Quarleri (2009) Rebelión y guerra en

47. Erbig Jr., op., cit.

48. Las implicancias de los acuerdos estudiados en términos del desarrollo del contrabando no ha sido abordados por la literatura específica. Solo encontramos textos que se refieren a las características que adquirió esta actividad en el Río de la Plata antes de la firma de los mismos, fundamentalmente a partir de la constitución de la Colonia de Sacramento (1680). En este sentido se entienden los efectos del contrabando en la organización del aparato militar, administrativo, en la formación de una elite local en el Río de la Plata y en las relaciones sociales que se entablan entre comerciantes portugueses, españoles y parcialidades indígenas. Al respecto ver Z. Moutoukias, Contrabando, y control colonial en el siglo XVII. Buenos Aires, el Atlántico y el espacio peruano, Buenos Aires, 1988 y P. Possamai, Colonia de Sacramento. Vida cotidiana durante la ocupación portuguesa. Montevideo, 2014. 
las fronteras del Plata. Guaraníes, jesuitas e imperios coloniales y de Luiz Tau Golin (2014) A guerra guaranítica. O levante indígena que desafiou Portugal e Espanha analizan el proceso de formación de las misiones guaraníticas y su resistencia ante el avance de los demarcadores ibéricos ${ }^{49}$. Estos estudios señalan el papel que desempeñaron las misiones como modo de ocupación territorial sobre el alto Paraná e Uruguay.

Mientras la formación militar recibida por los guaraníes garantizó la defensa frente a las incursiones de tropas regulares y milicianos a sueldo portugueses, las misiones (heterogéneas en sus características, con límites permeables) se constituyeron en ámbitos en que estos grupos étnicos pudieron contar con protección territorial. La firma del Tratado de Madrid actuó como un elemento de intervención sobre dinámicas locales que configuraban una frontera fluida, sujeta a los vaivenes de expansión, intercambio multiétnico, guerra y negociación.

Como muestra Tau Golin, la zona de intenso contacto estaba lejos de ser una línea geopolítica que separaba rígidamente a las tropas al servicio de la Corona portuguesa de los misioneros. Mientras las negociaciones se desarrollaban, soldados y aventureros contratados habían formado un gran campamento en los márgenes del río Jacuí, con 2.500 personas. En esta situación de espera e inmovilidad, luso-brasileños y nativos establecieron una activa relación comercial, que involucraba a los «enemigos». En este contexto, mientras los indígenas intercambiaban productos como charqui, harinas, yerba mate, animales y ponchos, las poblaciones occidentales ofrecían sombreros, hierro y cerámicas. Acampados aguas arriba del río, los aventureros provenientes de San Pablo se mostraban especialmente integrados en esa «mezcla de mundos», por ejemplo al dominar la lengua tupí a partir de la cual se entendían fácilmente con los guaraníes ${ }^{50}$.

La decisión del desalojo de las misiones y la guerra posterior redefinió las alianzas, y vínculos entre jesuitas, líderes indígenas y parcialidades que vivían en áreas aledañas a las misiones. A su vez, fueron emergiendo nuevas lideranzas indígenas con lealtades que podían ser propias a cada misión o transversal a todas aquellas que no deseaban abandonar las tierras que ocupaban. Para Quarleri en todo este proceso se visibilizó el encuentro entre distintas tradiciones de organización política y territorial guaraní y europea-jesuítica y colonial. Tanto antes de las guerras guaraníticas como luego de la derrota bélica, «los guaraníes fueron generando estrategias diferenciadas tendientes a recrear espacios autónomos frente a los nuevos contextos» ${ }^{51}$.

La perspectiva en cuestión tiene el innegable mérito de desplazar la discusión sobre los límites americanos de la disputa geopolítica entre las Coronas Ibéricas hacia la situación de las poblaciones indígenas que habitaban aquella región. Sin embargo, al hacerlo, concen-

49. Cabe señalar que las campañas militares de ambas Coronas buscando desalojar las misiones fueron llevadas adelante en los años 1754 y 1755-56.

50. L. C. Tau Golin, A guerra guaranítica. O levante indígena que desafiou Portugal e Espanha, São Paulo, 2014, 105-125.

51. L. Quarleri. Rebelión y guerra en las fronteras del Plata. Guaraníes, jesuitas e imperios coloniales, Buenos Aires 2009, 348. 


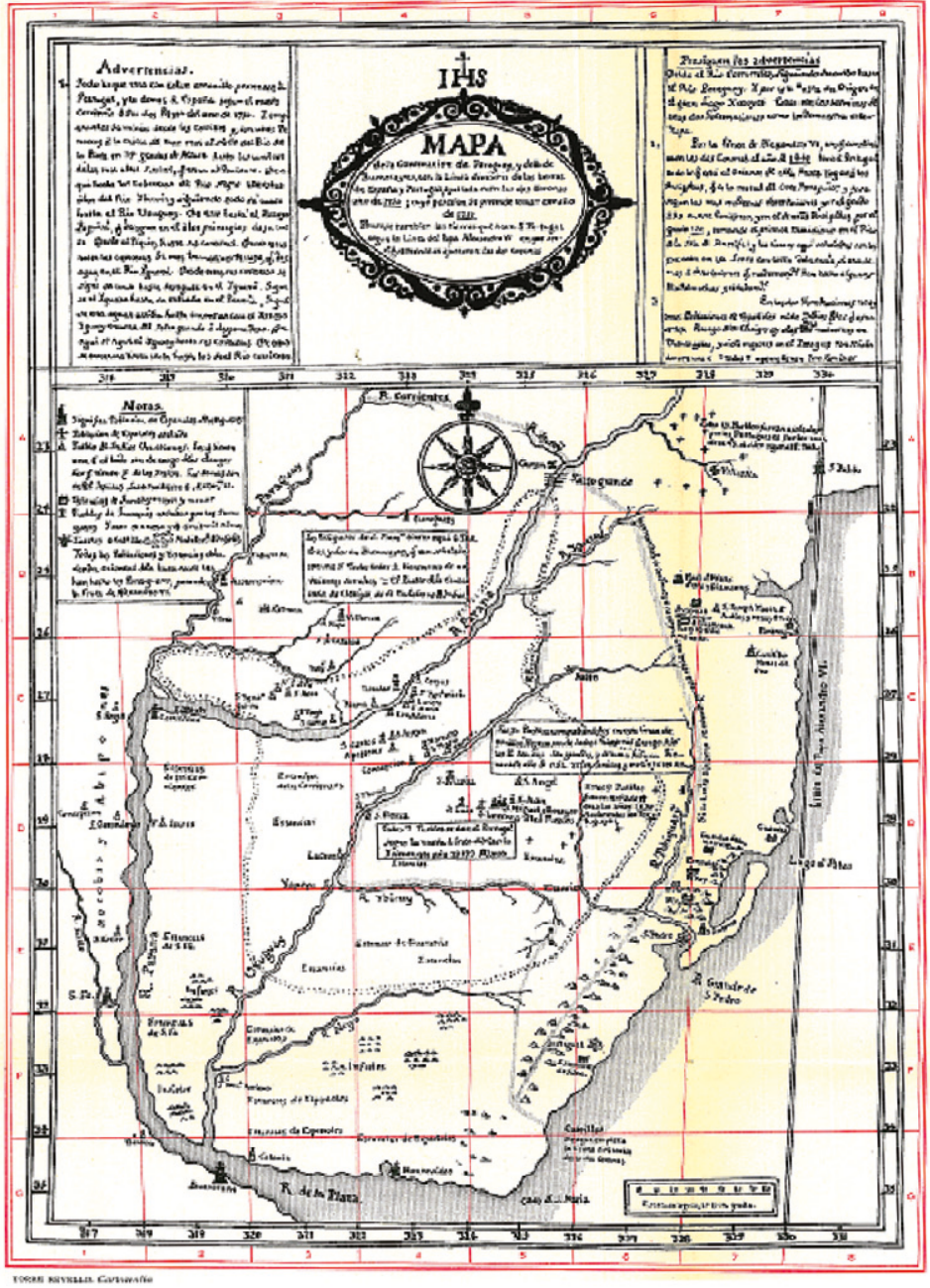

Figura 7. Padre José Cardiel. Mapa de la Governación del Paraguay y de la de Buenos Ayres, con la linea divisoria de tierras de España y Portugal, ajustada entre las dos Coronas año de 1750; cuya posesión se pretende tomar este año 1752. En: J. Torres Revello, Mapas y Planos del Río de la Plata conservados en el Archivo General de Simancas, Buenos Aires, 1938.

tra exclusivamente su interés en las reducciones indígenas organizadas por los jesuítas en el Alto Uruguay, compuestas básicamente por guaraníes. Aunque los trabajos mencionados no romantizan las misiones (vistas como una modalidad colonizadora y piezas de un proyecto geopolítico español), tienden a considerarlas de forma absoluta como representativas del universo indígena en el Plata, componiendo una tercera entidad territorial y societaria que rompería con el binarismo colonial. Estudios recientes realizados fuera del corpus delimitado en este artículo, han ofrecido un escenario más complejo de la región. Asi, además de las plazas coloniales y de los territorios misioneros, estos reconocen la existencia de «tolderías» en el espacio platino, agrupamientos de pueblos indígenas autónomos en relación a las Coronas y a la tutela jesuita. Estas formas de organización social, que llegaban a reunir un 
número expresivo de habitantes (de 50.000 a 100.000), establecían redes territoriales extensas con otros indígenas y colonizadores, hecho que ciertamente tuvo influencia en las campañas demarcatorias, dada la dependencia que estas mantenían de la ayuda nativa ${ }^{52}$.

\section{Tres perspectivas, tres visiones sobre el territorio y la frontera}

Las tres propuestas identificadas realizan tres lecturas distintas de los tratados en cuestión y suponen diferentes visiones del territorio y de la frontera colonial. En la primera propuesta los límites definidos por los tratados ofrecen una parte del contorno del territorio "deseado" por los Estados Nacionales en su proceso de conformación, a partir de su integración a los respectivos mitos de origen. Mientras que en el caso de Brasil, se otorga mayor relevancia al Tratado de Madrid por ser aquel que participa en la recreación del mito de la "Isla-Brasil" y de avance de la frontera hacia el Oeste, en el de Argentina, se recupera el Tratado de San Ildefonso pues a través del mismo, la representación del Virreinato del Río de la Plata puede incorporar las Misiones Orientales. A su vez, desde esta perspectiva los tratados diseñan un límite que se presenta como línea imaginaria (que solo adquiere contigüidad y materialidad en la cartografía) y que actúa como elemento de diferenciación de los territorios naturalmente heredados por Brasil y Argentina. Los estudios recientes ponen en cuestión las bases del mito de origen, al destacar el distanciamiento entre la narrativa cartográfica que lo sustenta y los procesos sociales y políticos que definieron el territorio de los Estados Nacionales. Estos procesos supusieron encuentros y desencuentros entre las elites regionales, negociaciones, diseños de distintos proyectos estatales y territoriales que la propia narrativa mítica monolítica acabo apagando.

En la segunda perspectiva el interés por el estudio de las prácticas, saberes y técnicas de las partidas demarcadoras permite poner en cuestión la visión esencialista y naturalizante del territorio propia de la perspectiva anterior, y mostrar el carácter a la vez científico y político de su construcción. A partir de la actuación de las partidas demarcadoras, la decisión de las metrópolis entra en interacción con los pareceres de los científicos en el terreno. Ellos combinan los intereses diplomáticos coloniales con aquellos que tienen que ver con su preocupación por contribuir al avance de los conocimientos europeos en las áreas de la astronomía y de la historia natural. Sin embargo, los estudios identificados no dan cuenta del hecho que el conocimiento producido no es individual sino colectivo. Esto quiere decir que tanto la demarcación de la línea intercolonial como el conocimiento sobre las áreas exploradas resultan del diálogo intercultural que tiene lugar entre las prácticas y saberes de las poblaciones locales con aquellas que traen los miembros de las partidas demarcadoras.

Por último, la tercera propuesta entiende al territorio como una construcción inestable y conflictiva, que involucra alianzas y disputas entre distintos actores sociales (algunos situados en las metrópolis y otros en distintos lugares de los ámbitos coloniales). En este contexto, se destaca que el diseño del límite intercolonial, pensado en la metrópoli y llevado al terreno

52. Erbig Jr., op. cit. 
por las partidas demarcadoras, es puesto en cuestión por algunos actores locales. De hecho, las poblaciones guaraníticas, no interesadas en abandonar las misiones, en su interacción con los jesuitas y con otras parcialidades indígenas resisten y reconfiguran los intereses de las metrópolis. En definitiva la firma de los Tratados desencadenó un conjunto de dinámicas sociales y políticas no esperadas por las propias Coronas que dificultaron la concreción de sus objetivos con consecuencias políticas y territoriales en los procesos de formación de los Estados Nacionales de América Meridional. 